\title{
ZNAČAJI ULOGA PRIVATNIH VOJNIH KOMPANIJA U REŠAVANJU SAVREMENIH PROBLEMA NACIONALNE I MEĐUNARODNE BEZBEDNOSTI
}

\author{
Nikola Vračević \\ Ministarstvo unutrašnjih poslova Republike Srbije \\ Vladimir M. Cvetković \\ Univerzitet u Beogradu, Fakultet bezbednosti
}

Ditanje sistema unutrašnje bezbednosti države i dalje nastavlja da zaokuplja veliku pažnju kako međunarodne javnosti, tako i političkih činilaca i običnih ljudi u mnogim zemljama. Takva situacija je postala očigledna, imajući u vidu sve učestalije terorističke aktivnosti na međunarodnom planu i probleme koji nastaju delovanjem organizovanih transnacionalnih kriminalnih grupa. Rukovodeći se time, a polazeći od pregleda strane i domaće literature, autori u prvom delu rada opisuju karakteristike sukoba niskog intenziteta sa osvrtom na slabe države, zatim razmatraju konceptualne osnove privatnih vojnih kompanija, kao i njihovu povezanost sa mirovnim misijama Ujedinjenih nacija i privatne vojne kompanije kao multiplikatore oružanih snaga. U drugom delu rada, autori analiziraju i sagledavaju ulogu privatnih vojnih kompanija u eksploataciji prirodnih resursa u zemljama visokog bezbednosnog rizika, ali i njihovu ulogu u sistemu unutrašnje bezbednosti i borbe protiv organizovanog kriminala.

Ključne reči: bezbednost, privatne vojne kompanije, nacionalna i međunarodna bezbednost, uloga

Uvod

U Parizu, 14. decembra 1995. godine, Republika Bosna i Hercegovina, Republika Hrvatska, i Savezna Republika Jugoslavija potpisale su Dejtonski sporazum, kojim je okončan građanski rat u Bosni i Hercegovini. To je bio surovi etnički konflikt u centralnoj Evropi, koji je počeo 1992. godine. U cilju primene i poštovanja potpisanog mirovnog sporazuma, kao i garancije mira u Bosni i Hercegovini, pod komandom Severnoatlantskog saveza (North Atlantic Treaty Organization - NATO), tj. NATO-a, u zemlju su došle multinacionalne vojne snage (Implementation Force, Bosnia and Herzegovina - IFOR). IFOR se januara 1996. godine transformisao u Stabilizacione snage (stabilization force - SFOR). Generalna skupština Ujedinjenih nacija je u toj zemlji odobrila i osnivanje Međunarodne policijske radne grupe (International Police Task Force - IPTF), takođe, pod komandom Ujedinjenih nacija.

\footnotetext{
${ }^{1}$ Videti opširnije na: http://www.un.org/Depts/DPKO/Missions/unmibh_p.htm. Pristupljeno 15.09.2018. godine.
} 
Paralelno sa aktivnostima NATO-a i Ujedinjenih nacija, 9. jula 1996. godine, tadašnji predsednik SAD Bil Klinton (Bill Clinton) objavio je početak programa „Treniraj i opremi“ (Train-and-Equip Program - TEP) koji je bio namenjen Bosanskoj Federaciji. Cilj ovog programa bio je da se pomogne Bosni kako bi stvorila svoje odbrambene snage. ${ }^{2}$ Početak rada TEP obeležio je dolazak oko 170 iskusnih i dobro obučenih pripadnika vojnih, policijskih i bezbednosnih snaga, koje su došle u Bosnu pod komandom Vilijama M. Bojsa (William M. Boyce), bivšeg komandnog generala Prve oklopne divizije u Nemačkoj. TEP je bio veoma ambiciozan i dobro osmišljen program, koji je podrazumevao pomoć oko formiranja novog ministarstva odbrane Federacije, kao i pomoć prilikom planiranja i sprovođenja vojne obuke. ${ }^{3}$ SAD su pomogle ovaj program sa oko 100 miliona dolara, dok su Saudijska Arabija, Kuvajt, Ujedinjeni Arapski Emirati, Malezija, i Brunej priložili oko 140 miliona dolara kako bi se pokrili svi troškovi TEP. U operativnom smislu, TEP je predstavljao nezavisan poduhvat nad kojim NATO i Ujedinjene nacije nisu imale ni autoritet, ni komandu. Međutim, ono što izdvaja TEP od ostalih vojnih operacija sponzorisanih od strane SAD bilo je to što je nosilac ovog programa, u stvari bila jedna privatna vojna kompanija, MPRI Inc. ${ }^{4}$

$M P R I$ i druge privatne vojne kompanije, koje su se pojavile na Balkanu u drugoj polovini 90-ih godina prošlog veka, uglavnom su učestvovale u poslovima rekonstrukcije objekata i obnove infrastrukture nakon završetka oružanih sukoba. Međutim, pre mirovnih sporazuma, u vreme kada su državne vojno-policijske snage, kao i razne paravojne formacije činile monstruozne zločine, a ratno okruženje privlačilo veliki broj džihadista i plaćenika, MPRI je pomogla vladi, tada nove, republike Hrvatske, kako bi stvorila nove i unapredila postojeće policijske, vojne i odbrambene kapacitete. ${ }^{5}$ Privatne vojne kompanije koje su trenutno aktivne u ovom delu Evrope uglavnom su fokusirane na pružanje bezbednosnih usluga, kao i usluga koje uključuju čišćenje terena od minsko-eksplozivnih sredstava zaostalih iz vremena rata u bivšoj Jugoslaviji. Pored toga, još uvek je aktuelno i pružanje usluga koje se odnose na vojnu i policijsku obuku. Usluge privatnih vojnih kompanija koriste mnoge države, multinacionalne korporacije, međunarodne i humanitarne organizacije, ali i privatni klijenti, kako bi ostvarili svoje političke, ekonomske, i humanitarne ciljeve. Ove ciljevi imaju veliki uticaj na međunarodnu bezbednost i mogu baciti potpuno novo svetlo na privatne vojne kompanije i njihove aktivnosti.

\footnotetext{
${ }^{2}$ National Archives and Records Administration, United States. President (1993-2001: Clinton), Bill Clinton, United States. Office of the Federal Register.: Public Papers of the Presidents of the United States, William J. Clinton, 1996, Book 2, July 1 to December 31. Washington: Government Printing Office, 2000, str. 1088.

${ }^{3}$ Ortiz, C.: "The New Public Management of Security. The Contracting and Managerial State and the Private Military Industry." Public Money and Management 30, br. 1 (2010): str. 35-41; Ortiz, C.: "The Private Military Company: An Entity at the Centre of Overlapping Spheres of Commercial Activity and Responsibility," in Private Military and Security Companies: Chances, Problems, Pitfalls and Prospects (ed. Thomas Jäger and Gerhard Kümmel). Wiesbaden, Germany: VS Verlag, 2007, str. 55-68.

${ }^{4}$ Ortiz,C.: "The Private Military Company: An Entity at the Centre of Overlapping Spheres of Commercial Activity and Responsibility," in Private Military and Security Companies: Chances, Problems, Pitfalls and Prospects (ed. Thomas Jäger and Gerhard Kümmel). Wiesbaden, Germany: VS Verlag, 2007, str. 55-68.

${ }^{5}$ Singer, P.W.: Corporate Warriors: The Rise of the Privatized Military Industry. New York: Cornell University Press, 2003, str. 119-125.
} 


\section{Sukobi niskog intenziteta i „slabe države“}

Slabe države spadaju među najnerazvijenije zemlje na svetu. U Tabeli 1. nalazi se lista slabih država koja je napravljena na osnovu istraživanja Svetske banke (World Bank) i Ujedinjenih nacija. Ova tabela uključuje: (1) države koje su okarakterisane kao „krhke“ ili nestabilne od strane incijative, države sa niskim prihodima i problemima (Low-Income Countries under Stress LICUS), koju je donela Svetska banka; i (2) države koje su uzete u razmatranje od strane Programa Ujedinjenih nacija za razvoj (UN Development Programme - UNDP), koje se karakterišu kao države sa niskim društvenim razvojem ("low human development" - $L H D$ ). Ova lista nudi informacije o najugroženijim državama na svetu, na način kako su one viđene od strane vodećih međunarodnih organizacija. Većina ovih država nalazi se u Africi. Konflikti u slabim državama su najčešće interne prirode (unutardržavni konflikti) koji nastaju pod uticajem etničkih, plemenskih ili religioznih nesporazuma i sukoba. Ovi konflikti mogu biti uzrokovani i sporovima vezanim za kontrolu nad prirodnim resursima, ali, generalno, to su sukobi niskog intenziteta.

Za razliku od konvencionalnih ratova između država (međudržavnih ratova), u kojima je cilj što efikasnije pobediti neprijatelja, uz upotrebu maksimalne sile, sukobe niskog intenziteta karakterišu povremena oružana dejstva u dužem vremenskom periodu. Na primer, dok je Demokratska Republika Kongo iskusila periodične ustanke od kada je stekla svoju nezavisnost od Belgije, 1960. godine, građanski rat u Somaliji se vodio nesmanjenom žestinom do ranih 90 -ih godina prošlog veka. Obe države su okarakterisane kao LICUS, a od strane Svetske banke definisane kao države koje se „karakterišu slabom politikom, institucijama, i upravljanjem.“6 „Sukob niskog intenziteta“, termin koji je prvi put bio upotrebljen za vreme hladnog rata, odnosi se na oružani sukob koji uključuje gerilsku i terorističku taktiku. Kombinovana upotreba obe ove taktike često se smatra kao oblik neregularnog ratovanja. Ubistva, zasede, bombaški napadi, otmice, vojni udari i zastrašivanje civilnog stanovništva, redovna su pojava u ovakvim oružanim sukobima.

Tabela 1 - Slabe države

(Izvor: istraživanje Svetske banke i Ujedinjenih nacija)

\begin{tabular}{|c|c|c|c|c|c|c|c|c|}
\hline $\bar{A}$ & $\sim$ & Angola & $\bar{A}$ & * & Gambija & $A$ & * & Ruanda \\
\hline & + & Avganistan & A & $\sim$ & Gvineja & A & * & Sjera Leone \\
\hline A & * & Benin & A & $\sim$ & Gvineja Bisao & & + & Solomonska ostrva \\
\hline A & * & Burkina Faso & & + & Haiti & A & + & Somalija \\
\hline A & $\sim$ & Burundi & & + & Kosovo & A & + & Sudan \\
\hline & + & Kambodža & & + & Laos NDR & & $\sim$ & Timor Leste \\
\hline A & $\sim$ & $\begin{array}{l}\text { Centralnoafrička } \\
\text { Republika }\end{array}$ & A & * & Lesoto & A & $\sim$ & Togo \\
\hline A & * & Čad & A & $\sim$ & Liberija & A & $*$ & Uganda \\
\hline A & + & Komori & A & * & Malavi & & + & Vanuatu \\
\hline A & $\sim$ & Kongo & A & * & Mali & A & + & Istočna obala i Gaza \\
\hline A & $\sim$ & Obala slonovače & A & * & Mozambik & A & * & Zambija \\
\hline A & $\sim$ & $\begin{array}{c}\text { Demokratska } \\
\text { Republika Kongo }\end{array}$ & & + & Mijanmar & A & + & Zimbabve \\
\hline A & $\sim$ & Eritreja & A & * & Niger & & & \\
\hline A & * & Etiopija & A & $\sim$ & Nigerija & & & \\
\hline \multicolumn{3}{|c|}{ (+) LICUS 2006. god. } & (*) LHD 2 & 06. god. & \multicolumn{3}{|c|}{ ( ) LICUS i LHD } & (A) Afrika \\
\hline
\end{tabular}

${ }^{6}$ World Bank Independent Evaluation Group, Engaging with Fragile States: An IEG Review of World Bank Support to Low-Income Countries under Stress 2006. Washington, DC: World Bank, 2006, str. 3. 
Poluautomatske i automatske puške, ručni raketni bacači, mačete, i dr. su osnovna oružja koja koriste pobunjenici, milicije i terorističke frakcije u oružanim sukobima niskog intenziteta. Automatske puške sistema „kalašnjikov“ (model AK-47) i ručni raketni bacači granata (model RPG-7) spadaju u najpopularnije oružje. Razlog je taj što su takva oružja relativno jeftina, mogu se lako nabaviti (bilo da je reč o novim ili polovnim) i, što je najvažnije, lako se održavaju i popravljaju. Ipak, Hutsu plemena su 1994. godine uglavnom koristila mačete kada su masakrirali oko 800.000 pripadnika plemena Tutsi, za vreme genocida u Ruandi, a mačete su koristili i pripadnici milicije Revolucionarnog ujedinjenog fronta (Revolutionary United Front RUF), 90-ih godina u Sijera Leoneu, kada su odsecali ruke ili noge zarobljenim vojnicima ili civilima. Ruanda i Sijera Leone, spadaju u grupu zemalja niskog društvenog razvoja ( $L H D$ zemalja), a od strane UNDP okarakterisane su kao zemlje jako niskog životnog standarda, nivoa obrazovanja stanovništva, kao i niskih materijalnih prihoda. Sukobi niskog intenziteta, lako mogu da se preliju i van granica zemlje u kojoj su nastali. Na primer, neprijateljstva između Hutsu i Tutsi plemena izazivala su tenzije preko graničnih oblasti između Ruande i Demokratske Republike Kongo. Pored toga, deficit ili nepostojanje vojnih i policijskih snaga utiče na porast kriminalnih aktivnosti u oblastima zahvaćenim sukobima niskog intenziteta. Tako je, na primer, došlo i do stvaranja glavne tranzitne tačke na kokainskom putu, koji vodi iz Južne Amerike do Evrope. ${ }^{7}$ To je zapadnoafrička zemlja Gvineja Bisau (okarakterisana u isto vreme i kao LICUS i kao LHD), koja danas ima status prve afričke narko-države.

Kada je reč o nerazvijenim zemljama i onim zemljama koje su sklone konfliktima, moramo biti veoma oprezni kako ne bismo primenili logiku „slabih država“ na neke druge države koje ne spadaju u ovu kategoriju, iako na prvi pogled sve ukazuje na to. Na primer, konflikt u Bosni i Hercegovini bio je brutalan, ali ova zemlja se ne može smatrati slabom državom. Postoje ozbiljni separatistički i teroristički problemi u Indiji, ali se ova zemlja od strane Ujedinjenih nacija smatra zemljom srednjeg društvenog razvoja (,medium human development" - MHD) i, prema mišljenju mnogih analitičara, predstavlja svetsku silu. Kampanja protiv organizacija koje se bave trgovinom narkoticima u Meksiku dovela je do toga da su neki gradovi u pograničnom području prema SAD postali veoma opasni. Međutim, Meksiko se smatra zemljom koja ima visok stepen društvenog razvoja, a ekonomija ove države rangirana je među prvih 20 u svetu.

Za vreme perioda bipolarnosti svet je bio podeljen na dva bloka. Na čelu ova dva bloka bile su dve supersile, SAD i SSSR. Zemlje Trećeg sveta bile su između i većina njih je naginjala ili ka Zapadu ili ka sovjetskoj strani. Ovo je naročito bilo izraženo u periodu hladnog rata, zbog koga su SAD i SSSR u jednom trenutku bili na ivici oružanog sukoba, ali nikada zvanično nisu jedno drugom objavili rat. Međutim, posledice hladnog rata bile su veoma vidljive $u$ nekim zemljama Trećeg sveta. Tu se pre svega misli na Afriku, Bliski istok i Jugoistočnu Aziju. Mnoge od ovih zemalja stekle su svoju nezavisnost za vreme perioda bipolarnosti. U ovoj grupi zemalja u razvoju nalaze se i one koje danas smatramo slabim državama. ${ }^{8}$ Kako je hladni rat napredovao, mnoge (slabe) države postale su narodne republike ili su se priklonile zapadnoj strani, a sve uz podršku i asistenciju supersila koje su se nalazile na čelu odgovarajućeg bloka. Ova asistencija se ogledala kako u vojnoj, tako i finansijskoj pomoći. Kraj bipolarnosti doveo je do drastične promene ovakvog odnosa. U slučaju SAD, broj vojnog osoblja (vojnici i ostali službenici zaposleni u Ministarstvu odbrane SAD) koje se 1983. godine nalazi-

\footnotetext{
${ }^{7}$ United Nations Office on Drugs and Crime. : Isto, str. 24.

${ }^{8}$ Ortiz, C.: Isto, str. 80.
} 
lo van granica zemlje smanjio se sa 520.000 na 344.000 1992. godine. ${ }^{9}$ Ovo smanjenje je praćeno padom prometa u trgovini naoružanjem i vojnom opremom u SAD, koje je 1987. godine iznosilo oko 23,6 milijardi dolara, na 14,8 milijardi dolara do kraja 1992. godine. ${ }^{10}$ Ekonomska kriza u Sovjetskom Savezu (Rusiji od 1991. godine) dovela je do pada društvenog, ekonomskog i socijalnog standarda u zemlji. Kao posledica toga, trgovina oružjem beleži drastičan pad. Sa oko 31,2 milijarde dolara, koliko je iznosila 1987. godine, pada na samo 2,8 milijarde dolara, 1992. godine. Sve ovo je uslovilo da SAD i njegovi saveznici budu mnogo jači i bolje organizovani nego oni predvođeni i podržavani od strane Rusije, Kine i drugih komunističkih zemalja. Demilitarizaciju i promenu odnosa snaga na svetskoj političkoj i vojnoj sceni nakon završetka hladnog rata mnogi su dočekali kao pomak koji je „bio neizbežan“. Uz vojnu pomoć supersila, slabe države su prošle kroz težak period, od siromašnih kolonija, do sticanja nekog oblika nezavisnosti. Ova vojna pomoć je nakon završetka hladnog rata polako počela da biva sve manja. U nekim slučajevima, ta pomoć je potpuno obustavljena dok je kod drugih ona prestala da bude bezuslovna. Drugim rečima, slabim državama bi strana pomoć bila uskraćena ukoliko ne bi uvele demokratiju i prihvatile reforme, nametnute sa strane.

Devedesete godine 20. veka bile su godine tranzicije. Transformacija svetske politike opet je dovela do stvaranja konflikata. Daleko od toga da je period bipolarnosti imao rešenje za ove konflikte, naprotiv, hladni rat im je samo "navukao ludačku košulju“ i držao ih pod kontrolom. Nakon završetka hladnog rata, kada je ta kontrola nestala, mnoge slabe države su postale žarišta ratova i oružanih sukoba niskog intenziteta. Pored toga, kontrola i disciplina koje su supersile imale nad slabim državama, kada je reč o korišćenju naoružanja i vojne opreme kojim su ih snabdevali, takođe je nestala. Kao rezultat toga, došlo je do velikog broja državnih i vojnih udara, a oružje i municija bili su krijumčareni od strane korumpiranih državnih zvaničnika, pa čak i šefova država. U suštini, oružje je veoma lako pronalazilo svoj put i dospevalo u pogrešne ruke. Između 1989. i 1997. godine, štokholmski Institut za istraživanje mira (Stockholm Peace Research Institute) izvestio je o smanjenju broja velikih oružanih konflikata sa 36 na $25 .{ }^{11}$ Uzrok ovome je verovatno „podela mira“, koja je nastala nakon završetka bipolarnosti na međunarodnoj bezbednosnoj sceni. Ipak, kraj bipolarnosti doveo je i do povećanja broja oružanih sukoba niskog intenziteta u slabim državama. Međunarodna javnost je bila uverena da će Ujedinjene nacije, oslobođene od raznih ograničenja koja su ih paralisala za vreme hladnog rata, odigrati veću ulogu u konfliktima koji su tek počinjali, ali to nije bio slučaj.

\section{Privatne vojne kompanije i mirovne misije Ujedinjenih nacija}

Ujedinjene nacije su zvanično nastale 24. oktobra 1945. godine, kada su Povelju Ujedinjenih nacija ratifikovali Kina, SSSR, Velika Britanija, SAD i većina drugih potpisnica. Ideja o potrebi stvaranja svetske organizacije sazrela je u toku Drugog svetskog rata, kada je sa-

\footnotetext{
${ }^{9}$ Vidi, Department of Defense, Annual Report to the President and the Congress. Washington, DC: Department of Defense, 1995, "Part V: Defense Management," http://www.dod.mil/execsec/adr95/index.html.

${ }^{10}$ Vidi, Tablicu 32 u International Institute for Strategic Studies, The Military Balance1998-1999. Oxford: Oxford University Press, 1998, str. 270.

${ }^{11}$ Vidi, Tablicu 1.1 u Stockholm Peace Research Institute, SIPRI Yearbook 1998: Armaments, Disarmament and International Security. Oxford: Oxford University Press, 1998, str. 20.
} 
vez zemalja, koji se borio protiv sila Osovine prihvatio ime „Ujedinjene nacije“ Deklaracijom od 1. januara 1942. godine, usvojenom u Londonu. ${ }^{12}$ Mirovne snage Ujedinjenih nacija su do 1998. godine već 50 godina bile aktivne na međunarodnoj sceni. Za to vreme, uspostavljeno je 49 mirovnih misija, u kojima je preko 750.000 vojnika i drugog osoblja služilo pod zastavom Ujedinjenih nacija. Ukupno 36 misija (oko 73 procenta) obavljeno je u periodu između 1988. i 1998. godine. ${ }^{13}$ Troškovi mirovnih misija Ujedinjenih nacija su 1993. godine premašili cifru od 3,6 milijardi dolara, što je predstavljalo polovinu ukupnih troškova mirovnih misija u 20. veku. Uzrok ovako velikim troškovima bila je mirovna misija u Somaliji (UNOSOM I i II) i početak velikog razmeštanja mirovnih snaga Ujedinjenih nacija u bivšoj Jugoslaviji (UNPROFOR, 1992-1995), odnosno misija u Bosni i Hercegovini (UNMIBH, 1995-2002), Hrvatskoj (UNCRO, 1995-1996; UNTAES, 1996-1998; UNMOP, 1996-2002; and UNPSG, 1998) i Makedoniji (UNPREDEP, 1995-1999). Troškovi mirovnih misija su smanjeni 1996. i 1997. godine, na oko 1,4 odnosno 1,3 milijarde dolara, respektivno. ${ }^{14}$ Predočeni podaci potvrđuju veću ulogu i angažovanje Ujedinjenih nacija na međunarodnom bezbednosnom planu nakon završetka hladnog rata, u periodu tranzicije. $U$ isto vreme oni ukazuju i na porast broja oružanih sukoba niskog intenziteta u svetu.

Spremnost nekih slabih država da angažuju privatne vojne kompanije kako bi postigle željene ciljeve, umesto da čekaju „plave šlemove“ (vojnici pod komandom Ujedinjenih nacija), postavlja pitanje efektivnosti i potrebe za mirovnim snagama Ujedinjenih nacija. Drugim rečima, nekim vladama (državama) postalo je jasno da moraju naći alternativno rešenje „posrnuloj“ spoljnoj pomoći, tj. često neefikasnim i sporim rešenjima koja su nudile Ujedinjene nacije. Angažovanje privatne vojne kompanije Izvršni ishodi (Executive Outcomes EO) u Angoli (LICUS i LHD ) i Sijera Leoneu (LHD) samo potvrđuje ove zaključke i stavlja Ujedinjene nacije i privatnu vojnu alternativu nasuprot jedno drugome, u veoma oštrom kontekstu. U nekim slučajevima humanitarne misije Ujedinjenih nacija služile su samo kao paravan ili izgovor za vojne ili političke operacije. To potvrđuje i primer intervencije nemačke armije u Somaliji 1993. godine u okviru operacije Ujedinjenih nacija. Cena ove intervencije iznosila je više od 6 milijardi franaka, dok stvarna humanitarna pomoć, koja je preko Nemačke stigla u Somaliju, nije iznosila više od 0,2 \% te sume. Cilj ovoga bio je da se prihvati ideja da nemačka armija ponovo ima pravo da interveniše van svoje zemlje. ${ }^{15}$

Između 1993. i 1997. godine, privatna vojna kompanija EO je bila angažovana u Angoli, gde je radila zajedno sa njenim vojnim snagama (Forças Armadas Angolanas $F A A$ ). Umešanost ove privatne vojne kompanije u oružane sukobe u toj zemlji bila je veoma kontroverzna. Ipak, bilo je veoma važno da FAA pobedi UNITA pobunjenike i preuzme kontrolu nad dijamantskim poljima. Kontrola nad dijamantskim poljima bila je važna kako bi se obezbedila sredstva za dalju borbu, ali i kako bi se vođstvo UNITA primoralo na pregovore (što je na kraju i dovelo do potpisivanja Lusaka mirovnih sporazuma). Pre dolaska EO, Ujedinjene nacije su već bile razmeštene u Angoli. Mirovna misija Ujedinje-

\footnotetext{
${ }^{12}$ Stajić, Lj.; Gilanović, Č.: Osnovi bezbednosti. Beograd: Policijska akademija u Beogradu, 1994.

${ }^{13}$ United Nations, "50 Years of United Nations Peacekeeping Operations, 1948-1998". New York: October 1998, http://www.un.org/en/peacekeeping/sites/50years/2.htm.

${ }^{14}$ United Nations, "United Nations Peacekeeping: Questions and Answers". New York, September 1998, http:// www.un.org/Depts/dpko/dpko/question/faq.htm.

${ }^{15}$ Milašinović, R ; Milašinović, S.: Uvod u teorije konflikata. Beograd: Fakultet civilne odbrane Univerziteta u Beogradu, 2004.
} 
nih nacija UNAVEM I (1988-1991) imala je zadatak da proprati i verifikuje povlačenje kubanskih trupa sa teritorije Angole, dok je cilj UNAVEM II (1991-1995) bio da verifikuje primenu prethodnog mirovnog dogovora između vlade Angole i UNITA (Bicese sporazumi). Ugovor između EO i vlade Angole procenjen je na 60 miliona dolara. ${ }^{16}$ Nasuprot tome, ukupni troškovi mirovnih misija UNAVEM / i // iznosili su oko 200 miliona dolara. ${ }^{17}$

Slično kao u Angoli, EO je u Sijera Leoneu doprineo neutralisanju RUF milicija i potpisivanju primirja, koje je dovelo do prestanka oružanih sukoba. Elizabet Rubin (Elizabeth Rubin) komentariše da pre dolaska i razmeštanja pripadnika $E O$ „niko ni Ujedinjene nacije, ni Organizacija afričkog jedinstva (Organization of African Unity), ni međunarodni eksperti za rešavanje konflikata, smešteni u napuštenom turističkom hotelu u Fritaunu (Freetown), glavnom gradu Sijera Leonea nije bio u stanju da dovede oružane sukobe pod kontrolu." "̇̇ Mala posmatračka misija Ujedinjenih nacija u Sjera Leoneu (UNOMSIL, 1998-1999) bila je naknadno uspostavljena. U međuvremenu, nakon što je EO napustio zemlju, jedna otcepljena RUF grupa, Momci sa zapadne strane (West Side Boys), uzela je oružje i sukobi su se nastavili. Kako bi asistirala u primeni Lome (Lomé) mirovnog sporazuma, kojim je konačno uspostavljen mir u Sijera Leoneu, u zemlju je poslata još jedna mirovna misija Ujedinjenih nacija, UNAMSIL (1999-2005). Troškovi ove misije iznosili su oko 2,8 milijardi dolara. Poređenja radi, „tarifa“ za angažovanje EO iznosila je oko 31 milion dolara godišnje. ${ }^{19}$ Pored toga, Dag Bruks (Doug Brooks) iznosi podatak da su privatne vojne kompanije Međunarodni DinKorp (DynCorp International) i PAE (PAE) obezbeđivale logističku podršku za UNAMSIL, dok je još jedna privatna vojna kompanija ICI $(I C I)$ iz Oregona, SAD, pružala usluge čarter letova za osoblje Ujedinjenih nacija i ambasade SAD. ${ }^{20}$ Troškovi koji variraju u milionima, a ne milijardama dolara, i stotine vojnika privatnih vojnih kompanija nasuprot hiljadama „mirovnjaka“ Ujedinjenih nacija, predstavljaju činjenice koje govore o dva suprotstavljena koncepta, tj dve suprotstavljene strategije kada je reč o rešavanju problema prouzrokovanih oružanim sukobima niskog intenziteta.

Ne postoje, niti se mogu naći drugi primeri koji bi na sličan način mogli opisati ono što je EO uspeo da postigne u Angoli i Sijera Leoneu. Sada već bivša, privatna vojna kompanija, Peščana linija (Sandline International), pokušala je da krene stopama EO. Ova kompanija je bila angažovana (unajmljena) od strane vlade Papua Nove Gvineje (do skoro LICUS), kako bi pružila pomoć njenim oružanim snagama da povrate kontrolu nad rudnikom uglja Panguna (Panguna), na ostrvu Buganvil (Bougainville). Ovaj rudnik je bio zatvoren nakon revolucije, kada je istoimena revolucionarna armija (Buganvil) preuzela kontrolu nad tim ostrvom. Plan privatne vojne kompanije, Peščana linija je uključivao angažovanje pripadnika EO, kroz neku vrstu podugovora. Međutim, zbog međunarodnog skandala koji je usledio, cela operacija je propala. Nakon ovoga, aspiracija za angažova-

\footnotetext{
${ }^{16}$ Vidi, Appendix B u Eeben Barlow.: Executive Outcomes: Against All Odds. Alberton, South Africa: Galago Books, 2007, str. 540.

${ }^{17}$ Činjenice i podaci vezani za sadašnje i bivše mirovne misije Ujedinjenih Nacija mogu se pronaći na Veb sajtu Sekretarijata mirovnih operacija Ujedinjenih Nacija: http:// www.un.org/en/peacekeeping/.

${ }^{18}$ Rubin, E.: "An Army of One's Own: In Africa, Nations Hire a Corporation to Wage War," Harper's Magazine (February 1997): str. 45.

${ }^{19}$ Vidi, Appendix B u Eeben Barlow, Isto, str. 540.

${ }^{20}$ Brooks, D.: "From Humble Beginnings in Freetown: The Origins of the IPOA Code of Conduct," Journal of International Peace Operations 3, no. 5, 2008, str. 9.
} 
njem privatnih vojnih kompanija za slične potrebe naglo je opala. Ipak, EO je dao kredibilitet ideji da privatne vojne kompanije u funkciji „multiplikatora oružanih snaga“, takođe, mogu doprineti stvaranju mira.

\section{Privatne vojne kompanije kao multiplikatori oružanih snaga}

„Multiplikacija sile“ je vojni termin koji se odnosi na relativno malu grupu vojnih specijalista koji mogu poboljšati i unaprediti veće snage (npr. vojsku ili jedinice unutar nje). U kontekstu koji se odnosi na privatne vojne kompanije, multiplikacija sile podrazumeva multiplikaciju oružanih snaga. ${ }^{21}$ Privatne vojne kompanije poseduju veštine i znanja koja u velikoj meri, u strategijskom, taktičkom, ili operativnom smislu, mogu poboljšati vojne, policijske i obaveštajne kapacitete svih onih bezbednosnih struktura koje zahtevaju njihovu pomoć ili usluge. Dok se strategija bavi opštim planovima i ciljevima, taktika se fokusira na to kako su vojne jedinice organizovane i raspoređene da bi se postigao određeni cilj. Kada se privatne vojne kompanije angažuju da sprovedu vojnu obuku (instruktažu vojnih snaga), po definiciji, one postaju multiplikatori sile. Prvo, one obezbeđuju stručno osposobljeni kadar koji nije povezan sa državnim snagama ili agencijama. Drugo, one vrše snabdevanje svojih ljudi (timova) koji obavljaju instruktažu ili koji se nalaze u okviru bezbednosnih snaga države koja je sklopila ugovor sa privatnom vojnom kompanijom. ${ }^{22} \mathrm{U}$ slučaju EO u Angoli i Sijera Leoneu, aktivnosti ove privatne vojne kompanije uključivale su strategiju, taktiku i operativnu podršku sve do borbenog nivoa. Međutim, u mnogo slučajeva, usluge privatnih vojnih kompanija koje se odnose na obuku su jako specifične i uglavnom se sprovode na lokacijama koje se nalaze daleko od zone borbenih dejstava, najčešće u formi kakav je bio TEP program.

Za vreme sprovođenja TEP programa, privatne vojne kompanije i vojno-industrijske korporacije (velike multinacionalne kompanije koje se bave proizvodnjom i prometom naoružanja i vojne opreme) uspostavljali bi nekakav oblik bezbednosnog partnerstva sa vladama, bilo da je reč o pružanju neke vrste trening usluga korisnicima, ili da je reč o unapređenju njihovih snaga. TEP program u Bosni i Hercegovini počeo je rad nakon što su vlada Bosne i Hercegovine i privatna vojna kompanija Vojni profesionalni resursi (Military Professional Resources - MPRI), potpisale ugovor. ${ }^{23}$ Još jedna privatna vojna kompanija, Kubna korporacija (Cubic Corporation), bila je uključena u TEP program koji je bio namenjen Gruziji (ovaj program je, takođe, bio sponzorisan od strane SAD). ${ }^{24}$ Pored toga, ova kompanija bila je uključena u slične programe u Rumuniji, Ukrajini i Litvaniji (dve bivše sovjetske republike). Izraelski instruktori su, takođe, bili uključeni u vojnu instruktažu nekih jedinica u Gruziji. Dok su Velika Britanija i ostale zemlje članice NATO-a bile uključene u slične programe, u oblastima (zemljama) pod njihovim uticajem, Izrael i SAD polako su preuzimali primat na polju privatne vojne i policijske instruktaže.

\footnotetext{
${ }^{21}$ Edwards, S.: Swarming On The Battlefield: Past, Present, And Future. San Diego: Rand Publishing, 2000, str. 25.

${ }^{22}$ Edwards, S.: Isto, str. 41.

${ }^{23}$ Van Metre L.; Akan, B.: Special Repot: Dayton Implementation: The Train and Equip Program. United States Institute of Peace, 1997, str. 2.

${ }^{24}$ Thomas, J.; Kümmel, G.: Private military and security companies: chances, problems, pitfalls and prospects. Wiesbaden: VS Verlag, 2007, str. 66.
} 


\begin{tabular}{|c|c|c|}
\hline $\begin{array}{c}\text { ВЛАДЕ } \\
\text { ДРЖАВА }\end{array}$ & $\begin{array}{l}\text { МЕЪУНАРОДНЕ } \\
\text { И НЕВЛАДИНЕ } \\
\text { ОРГАНИЗАЦИЈЕ }\end{array}$ & $\begin{array}{l}\text { ПРИВРЕДНИ } \\
\text { СУБЈЕКТИ }\end{array}$ \\
\hline $\begin{array}{c}\text { Политички } \\
\text { циљеви }\end{array}$ & $\begin{array}{l}\text { Хуманитарни } \\
\text { циљеви }\end{array}$ & $\begin{array}{c}\text { Економски } \\
\text { циљеви }\end{array}$ \\
\hline $\begin{array}{l}\text { Заштита } \\
\text { имовине }\end{array}$ & $\begin{array}{c}\text { Заштита виталних } \\
\text { постројења }\end{array}$ & $\begin{array}{c}\text { Заштита } \\
\text { инфрраструктуре }\end{array}$ \\
\hline \multirow{2}{*}{$\begin{array}{c}\text { Заштита } \\
\text { државних } \\
\text { функционера }\end{array}$} & \multirow{2}{*}{$\begin{array}{c}\text { Заштита хуманитарног } \\
\text { особља и избеглица }\end{array}$} & \multirow{3}{*}{\begin{tabular}{|c|} 
Заштита особља \\
Безбедан \\
транспорт људи \\
и опреме \\
\end{tabular}} \\
\hline & & \\
\hline Војна обука & \multirow{2}{*}{$\begin{array}{c}\text { Безбедан транспорт } \\
\text { људи и хуманитарних } \\
\text { добара }\end{array}$} & \\
\hline $\begin{array}{c}\text { Полицијска } \\
\text { обука } \\
\end{array}$ & & \multirow{2}{*}{$\begin{array}{c}\text { Безбедност на } \\
\text { морским путевима }\end{array}$} \\
\hline $\begin{array}{c}\text { Обавештајна } \\
\text { подршка }\end{array}$ & Процена ризика & \\
\hline $\begin{array}{c}\text { Борба } \\
\text { против }\end{array}$ & $\begin{array}{c}\text { Чишћење минских } \\
\text { поља }\end{array}$ & $\begin{array}{c}\text { Антитерористички } \\
\text { задаци }\end{array}$ \\
\hline $\begin{array}{c}\text { трговине } \\
\text { наркотицима }\end{array}$ & \multirow{3}{*}{$\begin{array}{c}\text { Уништавање } \\
\text { неексплодираних } \\
\text { убојних средстава }\end{array}$} & Процена ризика \\
\hline Полицијско & & \multirow{2}{*}{$\begin{array}{l}\text { Реаговање у } \\
\text { случају отмица }\end{array}$} \\
\hline \multirow{2}{*}{$\begin{array}{c}\text { Логистика и } \\
\text { размештање } \\
\text { снага }\end{array}$} & & \\
\hline & $\begin{array}{c}\text { Евакуација у ванредним } \\
\text { ситуацијама }\end{array}$ & \multirow{2}{*}{$\begin{array}{l}\text { Медицинска } \\
\text { помоћ у } \\
\text { теренским } \\
\text { условима }\end{array}$} \\
\hline Регрутација & \multirow{2}{*}{$\begin{array}{c}\text { Надгледање } \\
\text { поштовања мировних } \\
\text { споразума }\end{array}$} & \\
\hline $\begin{array}{c}\text { Задаци } \\
\text { унутрашње } \\
\text { безбедности } \\
\end{array}$ & & $\begin{array}{c}\text { Логистичка } \\
\text { подршка }\end{array}$ \\
\hline $\begin{array}{c}\text { Информационо- } \\
\text { технолошка } \\
\text { подршка, итд. }\end{array}$ & $\begin{array}{c}\text { Медицинска помоћ у } \\
\text { теренским условима, } \\
\text { итд. }\end{array}$ & $\begin{array}{l}\text { Информационо- } \\
\text { технолошка } \\
\text { безбедност, итд. }\end{array}$ \\
\hline
\end{tabular}

Slika 1 - Privatne vojne kompanije: ciljevi i zadaci. Izvor: obrada autora. 
Privatne vojne kompanije, takođe, mogu biti angažovane kao multiplikatori oružanih snaga u oblasti unutrašnje bezbednosti. Ovo se najčešće odnosi na policijske snage, odnosno na policijske poslove (borba protiv organizovanog kriminala, borba protiv trgovine narkoticima, borba protiv terorizma, itd). Na primer, privatna vojna kompanija Međunarodni DinKorp (DynCorp International), pored pružanja obuke vojnim jedinicama Liberije (LICUS i LHD), koje su brojale oko 4.000 pripadnika, obučavala je i nove policijske snage te zemlje. Ova privatna vojna kompanija je najviše bila zadužena za formiranje nove iračke policije, a trenutno se bavi sličnim poslovima u Avganistanu i drugim zemljama. Obuka i pomoć policijskim jedinicama, u operativnom i tehničkom smislu, povezana sa planom „Kolumbija“ i „Merida“ inicijativom (Merida Initiative), koje se odnose na Meksiko i Centralnu Ameriku, može biti protumačena kao protivnarkotički TEP. ${ }^{25}$ Privatne vojne kompanije su odigrale veoma značajnu ulogu u oba ova programa. Na slici 1. prikazan je model, napravljen na osnovu prethodne analize. On uključuje ciljeve koje korisnici usluga privatnih vojnih kompanija žele da ostvare kada sa njima sklapaju ugovore. Očigledno je da ima izvesnih preklapanja, imajući u vidu da se prilikom pokušaja uspostavljanja mira i stabilnosti u čitavim regionima politički ciljevi često prepliću sa humanitarnim, a u ceo proces, pored Ujedinjenih nacija, uključene su i druge strane.

$\mathrm{Na}$ osnovu ovih primera, može se zaključiti da privatne vojne kompanije mogu delovati kao multiplikatori oružanih snaga ne samo u slabim državama, nego i u zemljama u razvoju, kao i u naprednim demokratskim državama. U SAD i Velikoj Britaniji je korišćenje usluga privatnih vojnih kompanija postepeno uvođeno u praksu kao vid partnerstva u okviru bezbednosne industrije, gde privatne vojne kompanije, tj. njihovi instruktori aktivno učestvuju u obuci nove generacije vojnika. Pored toga, definicija „multiplikatora sile“ ubačena u vojni terenski priručnik "Kontraktori na bojištu“ (Contractors on the Battlefield), koji koriste oružane snage SAD, takođe se bavi „funkcionalnom podrškom u zoni borbenih dejstava“ i „sistematskom potrebom kontraktora da obezbede tehničku podršku. “26 Angažovanjem privatnih vojnih kompanija kao multiplikatora oružanih snaga, druga ugovorna strana pokušava da postigne političke ciljeve. Ovi ciljevi najčešće uključuju odvraćanje neprijatelja ili borbu protiv neprijateljskih snaga koje napadaju zvanične organe državne vlasti i podrivaju „mir i stabilnost“ u zemlji.

Model prikazan na slici 1, takođe, ilustruje različite usluge koje privatne vojne kompanije nude vladama raznih država, međunarodnim i nevladinim organizacijama i privrednim subjektima, kako bi ostvarili svoje političke, humanitarne i ekonomske ciljeve. Ovaj prikaz nudi drugačiji pristup razumevanju privatnih vojnih kompanija, u odnosu na konvencionalnu tipološku analizu baziranu na osnovu „ubojnosti“ usluga koje one nude.

\section{Uloga privatnih vojnih kompanija u eksploataciji prirodnih resursa u zemljama visokog bezbednosnog rizika}

Prema podacima Energetske informativne administracije (Energy Information Administration - EIA), ukupna ponuda nafte na svetskom tržištu 2006. godine iznosila je oko 84,52 miliona barela dnevno (jedan barel nafte približno sadrži 42 galona; jedan galon

\footnotetext{
${ }^{25}$ Ortiz, C.: Isto, str. 87.

${ }^{26}$ Department of the Army, Contractors on the Battlefield: Field Manual (FM 3-100.21). Washington, DC: Department of the Army, 2003, paras. 1-29.
} 
ima oko 3,78 litara), a dnevna potražnja oko 85,20 miliona barela. ${ }^{27} \mathrm{U} 2008$. godini, ukupna ponuda nafte na svetskom tržištu iznosila je 85,37 miliona barela dnevno, a dnevna potražnja 85,78 . miliona barela. ${ }^{28}$ Velika nalazišta nafte uglavnom su bila otkrivena za vreme hladnog rata. Ipak, države -,,super giganti“, kada je reč o kapacitetima njihovih naftnih nalazišta, ušle su u završnu fazu eksploatacije. Stručnjaci iz ove oblasti procenjuju da se otkrićem novih naftnih nalazišta (na primer, onih u zapadnoj Africi, Libiji, novim demokratskim zemljama u Kaspijskom regionu i Brazilu), kao i eksploatacijom još uvek nedovoljno istraženih oblasti (na primer, Iraka koji, kako je provereno, predstavlja treće najveće nalazište svetskih rezervi nafte), proizvodnja nafte može povećati na oko 95 miliona barela dnevno. Iznad tog nivoa, za jednu do dve decenije, ulazimo u neistraženu i još uvek nedovoljno ispitanu oblast.

Povećana potražnja, kao i želja za što većim profitom, kako velikih multinacionalnih korporacija tako i mnogih država, primorala je velike „energetske gigante“ da „kopaju mnogo dublje" i često na sve „opasnijim mestima“. Za vreme dok je FAA bila u ratu sa UNITA, tokom 90-ih godina 20. veka, u Angoli se nesmetano odvijala proizvodnja nafte. Ova nafta bila je eksploatisana na postojećim naftnim poljima, ali su u isto vreme vršena i istraživanja kako bi se pronašla nova nalazišta. Nova nalazišta nafte otkrivena su u Bloku 17, izvan priobalnog područja provincije Zaire (Zaire) u Angoli, oblasti u kojoj je privatna vojna kompanija EO započela svoje prve borbene operacije. Polja Žirasol (Girassol), zapadnoafrički projekat prvenac eksploatacije nafte u dubokim vodama, izgrađen je između 1998. i 2001. godine i koštao je oko 2,8 milijardi dolara. ${ }^{29}$ Multinacionalna korporacija TOTAL (Francuska), koja je vlasnik većinskog dela akcija, radi na ovom projektu zajedno sa kompanijama kao što su Ekson-Mobil iz SAD, Britiš petrol iz Velike Britanije i Statoil (Statoil) i Norsk Hidro (Norsk Hydro) iz Norveške. Za Angolu, profit ostvaren u naftnom sektoru predstavlja oko 90 procenata izvoza i 90 procenata ukupnih vladinih prihoda.

Odnos ponude i potražnje nafte na svetskom tržištu, brojčano posmatrano, veoma je „tesan“. Ovo u nekom smislu objašnjava zbog čega postoje česte kalkulacije, kada je reč o proizvodnji nafte koju diktira Organizacija zemalja izvoznica nafte (Organization of the Petroleum Exporting Countries - OPEC) ${ }^{30}$. Ovakva situacija u velikoj meri utiče na cenu nafte na svetskim berzama. Međutim, kada pobunjeničke ili terorističke grupe napadnu naftna nalazišta, ili sabotiraju proizvodnju na njima, takođe dolazi do promene u ceni nafte na svetskom tržištu, odnosno prilagođavanja cene novonastaloj situaciji. Proizvodnja nafte u Nigeriji, u proteklom periodu, bila je smanjena čak za petinu zbog intenzivnih napada od strane militantnih pripadnika Pokreta za emancipaciju delte Nigera (Movement for the Emancipation of the Niger Delta - MEND), koji su bili povezani sa organizovanim kriminalnim bandama. Kako je Nigerija jedan od pet glavnih proizvođača i distributera nafte za SAD, ovo je dovelo do velikog skoka cene ove sirovine. U julu 2008. godine, ce-

\footnotetext{
${ }^{27}$ Energy Information Administration, "September 2009 International Petroleum Monthly" (Washington, DC, November 10, 2009), http://www.eia.doe.gov/ emeu/ipsr/t21.xls.

${ }^{28}$ Ibid.

${ }^{29}$ Vidi, TOTAL, Girassol: A Stepping Stone for the Industry (Courbevoie, France: TOTAL, September 19, 2008), str. 31-36; i “Angola's Deepwater Girassol Field Comes on Stream," Press Release (Courbevoie, France, December 4, 2001).

${ }^{30}$ Zemlje članice OPEC su: Alžir, Angola, Ekvador, Indonezija, Iran, Irak, Kuvajt, Libija, Nigerija, Katar, Saudijska Arabija, Ujedinjeni Arapski Emirati, i Venecuela.
} 
na sirove nafte iznosila je čak 147 dolara po barelu. ${ }^{31}$ Pored napada pobunjenika, postoji veliki broj rizika i bezbednosnih problema koji pogađaju zemlje proizvođače nafte.

U zemljama sa konfliktnom prošlošću, otmice i nasilna ponašanja prema stranim radnicima, oštećenja ili sabotaže industrijskih postrojenja i instalacija, kao i krađa nafte direktno iz cevovoda, uobičajene su pojave. U Kolumbiji, kao i u Nigeriji, prisutne su uglavnom sve velike multinacionalne energetske korporacije. Kao i MEND, Revolucionarne oružane snage kolumbije (Revolutionary Armed Forces of Colombia - FARC), koriste siromaštvo naroda, ali i retoriku (koju provlače kao brigu o zaštiti životne sredine) kako bi opravdali štetu koju svakodnevno nanose naftnoj infrastrukturi te zemlje. ${ }^{32} \mathrm{U}$ junu 2008. godine, cevovod za transport nafte koji vodi do luke Kovenas (Covenas) na karipskoj obali Kolumbije zatvoren je nakon napada koji je sproveo FARC (napad je izveden dinamitom). Takođe u junu, iste godine, oko 30 MEND militanata na gliserima napali su naftno polje (naftna platforma na moru) Bonga (Bonga), najveće postrojenje kompanije Rojal Dač Šel, u vodama Nigerije. Ovaj napad napravio je presedan. ${ }^{33}$ Naime, najveći deo nafte proizveden u zalivu Gvineje i zapadnoj Africi dolazi sa naftnih platformi na otvorenom moru, koje su sve do tog događaja smatrane nedodirljivim.

Istočno od Nigerije nalazi se Gana, izabrana u julu 2009. godine od strane predsednika SAD Baraka Obame (Barack Obama) za jednu od njegovih destinacija prilikom prve zvanične posete potsaharskoj Africi. Gana je jedan od velikih izvoznika kakaa i zlata; u zemlji se održavaju višestranački izbori od 1992. godine; kategorisana je prema UNDP kao MHD, a prema podacima Svetske banke ekonomski rast zemlje, od 2000. godine, iznosi u proseku oko 3,9 procenata godišnje. ${ }^{34}$ Ekonomski napredak Gane je daleko od idealnog. S tim u vezi, ova zemlja bi mogla mnogo bolje da iskoristi prirodna bogatstva kojima raspolaže i da na taj način svom stanovništvu obezbedi veći društveni standard i prosperitet. Spoljna finansijska pomoć je u velikoj meri prisutna u Gani i zbog toga ona napreduje mnogo bolje od većine potsaharskih zemalja. Ali, onda je na scenu stupila nafta i stvari su se zakomplikovale.

Godine 2007, naftna kompanija iz Velike Britanije koja je prisutna u više od desetak potsaharskih zemalja, Tulov nafta (Tullow Oil), otkrila je veoma važno i veliko naftno nalazište u blizini obala Gane: polje Jubile (Jubilee). ${ }^{35}$ Ovo naftno polje, kao i ostala nalazišta nafte u toj zemlji, mogu preko noći promeniti ekonomsku perspektivu Gane. Ili će Gana uspeti da kontroliše i eksploatiše ova novootkrivena prirodna bogatstva i dobiti finansijski podsticaj (kako bi prešla na novi stepenik ekonomskog razvoja), ili će nafta postati njeno prokletstvo. Veoma brzo to naftno bogatstvo može da stvori autokratske vlade, korupciju, vojne pučeve, pa čak i velike ustanke (pobune). Jednom rečju, bilo da se radi o nafti ili su u pitanju neka druga prirodna bogatstva, neočekivana dešavanja mogu da dovedu do ugrožavanja demokratskih struktura u jednoj zemlji. Dok je Gana bila prva potsaharska afrička zemlja koja je stekla svoju nezavisnost 1957. godine, Gabonom je sve

\footnotetext{
${ }^{31}$ Videti opširnije na: http://www.cfr.org/nigeria/mend-niger-deltas-umbrella-militant-group/p12920. Pristupljeno: 15. novembra 2018. godine u 15 časova.

${ }^{32}$ Ramirez, F.: The profits of extermination: how U.S. corporate power is destroying Colombia. Monroe, Common Courage Press, 2005, str. 39.

${ }^{33}$ Preuzeto 11. novembra 2018. godine sa http://news.bbc.co.uk/2/hi/7419918.stm

${ }^{34}$ Kwame Boafro, A.: Ghana: one decade of the liberal state. London: Zed Books, 2007, str. 120.

${ }^{35}$ Videti opširnije na: http://www.tullowoil.com/index.asp?pageid=52. Pristupljeno 11. novembra 2018. godine u 14 časova.
} 
do juna 2009. vladao predsednik Omar Bongo (Omar Bongo), koji je bio na vlasti od 1967. godine. Oko 50 procenata prihoda Gabona dolazi od nafte. Naftne ekonomije kojima vladaju autokrate otkrivaju velika bogatstva koja se nalaze u rukama nekolicine ljudi, kao i velike socijalne i društvene nejednakosti. Ljudska prava i građanske slobode u takvim državama odgovaraju samo onima koji su favorizovani od strane režima na vlasti. ${ }^{36}$ $\mathrm{U}$ istu grupu spada i Teodoro Obiang (Teodoro Obiang), koji je bio predsednik Ekvatorijalne Gvineje, pošto je preuzeo vlast u vojnom puču 1976. godine, ali i Muamer al Gadafi (Muammar al-Gaddafi), koji je u Libiji na vlast došao, takođe, vojnim udarom, 1969. godine (Gadafi je 2011. godine svrgnut za vlasti i ubijen, nakon pobune u zemlji potpomognute od strane zapadnih zemalja i SAD). Idris Debi (Idriss Déby) je promenio ustav Čada 2006. godine kako bi se mogao po treći put kandidovati za predsedničku funkciju. Na čelu države, Debi je dva puta bio suočen sa pučevima, 2006. i 2008. godine, i samo je pitanje dana kada će biti svrgnut sa vlasti. Dok su autokrate jedno vreme držali neke države na okupu, zemlje poput Nigerije i Čada prošle su mnogo vojnih pučeva i promenile dosta vladara za vreme njihove istorijske težnje i želje da postanu nezavisne države. ${ }^{37}$

Nijedna zapadna nacija ili proizvođač nafte u Africi kao ni drugi regioni sveta koji se ekonomski razvijaju, ne mogu bez posledica da se izvuku iz ove igre nafte. Evropske sile su pokušavale da održe uticaj nad svojim bivšim kolonijama nakon sticanja njihove nezavisnosti. Ovaj uticaj je podrazumevao obezbeđivanje koncesija ili povlašćeni položaj za njihove nacionalne kompanije, od strane vladara koji su pristajali na takav odnos. Naime, 2008. godine, BBC $(B B C)$ je u jednoj emisiji, koja se bavila biografijom Idrisa Debija, objavio da je on došao na vlast uz podršku i asistenciju francuske obaveštajne službe, nakon državnog puča 1990. godine. ${ }^{38}$ Omar Bongo je, takođe, imao „specijalne“ veze sa francuskim establišmentom, sve dok nedavna antikorupcijska istraga nije dovela do zaplene njegove imovine u Francuskoj. Vremena se menjaju i zapadne vlade ne mogu više tako lako da se distanciraju od mračnih detalja svojih sumnjivih saveza. Vilijam Reno (William Reno) je možda u pravu kada kaže da ponekad stranci više vole da sarađuju sa vladarima koji deluju pod plaštom globalno priznatog suvereniteta, nego da pokušavaju da izgrade odnose sa diktatorima, koji za njih predstavljaju konkurenciju ili u isto vreme nemaju uticaj i podršku svog naroda. ${ }^{39}$

Bilo da je reč o istraživanju i eksploataciji nafte, ili, pak, o njenoj preradi i distribuciji, jednom kada velike multinacionalne naftne korporacije ulože milijarde dolara u poslove ili projekte u nekoj državi, one se ne mogu jednostavno preseliti ili povući. O bezbednosti njihovih ljudi i investicija ponekad brinu bezbednosne snage država u kojoj te korporacije rade i posluju. Ovo, međutim, predstavlja osnovni vid zaštite, koji je uglavnom nedovoljan da izdrži talase nestabilnosti ili bezbednosne probleme koji mogu nastati u tim državama. Pored toga što sve velike multinacionalne naftne korporacije imaju sopstvene timove za obezbeđenje i zaštitu personala i infrastrukture kompanije (posebna odeljenja u okviru velikih kompanija koja su zadužena za bezbednost), poslovi bezbednosti, zaštite i procene rizika obično se poveravaju privatnim vojnim kompanijama, sa kojima se i sklapaju ugovori o poslovnoj saradnji.

\footnotetext{
${ }^{36}$ Ghazvinian, J.: Untapped: The Scramble for Africa's Oil. New York: Harcourt, 2008, str. 257.

${ }^{37}$ Adeniran, W.: Democracy and military dictatorship in Africa. Lagos: Shalom Goldlinks Concept, 2003, str. 58.

${ }^{38}$ BBC. "Profile: Idriss Deby." BBC News, February 2, 2008.

${ }^{39}$ Reno, W.: "African Weak States and Commercial Alliances," 96, no. 383 African Affairs, 1997, str. 167.
} 
Nasuprot popularnim stereotipima, privatne vojne kompanije nisu angažovane niti se spremaju da dođu u svaku državu u kojoj velike energetske korporacije imaju svoje poslove koji se odnose na eksploataciju prirodnih resursa. Usluge koje ove kompanije nude ipak su malo specifične. Privatne vojne usluge obično podrazumevaju male timove koje čine bivši visokoobučeni pripadnici vojske ili policije, koji za potrebe većih poslova angažuju, tj. zapošljavaju lokalne bezbednosne firme ili njihovo ljudstvo. Privatne vojne kompanije, kao što su: Andreus Internacional (Andrews International), G4S (G4S), Garda svetska bezbednosna korporacija (Garda World Security Corporation) i drugi, u većoj ili manjoj meri angažovani su u ovoj oblasti. ${ }^{40}$ Analiza uloge privatnih vojnih kompanija u eksploataciji prirodnih resursa u zemljama visokog bezbednosnog rizika je uprošćena, imajući u vidu da su izostavljena imena mnogih velikih energetskih korporacija, kao i na desetine malih nezavisnih firmi (Tullow Oil je samo jedan od primera). Privatne vojne kompanije takođe su uključene u poslovne aranžmane sa ovim manjim firmama. Nekada one samo pružaju bezbednost i zaštitu, ali u nekim slučajevima između nezavisnih naftnih kompanija i privatnih vojnih kompanija uspostavljaju se i jače komercijalne veze.

U Tabeli 2. nalazi se lista izabranih zemalja proizvođača nafte i gasa, kao i njihov nivo razvoja (ustanovljen prema UNDP). Pored toga, u tabeli je prikazan rizik i bezbednosni problemi karakteristični za te zemlje. Pod pojmom slabe države smatraju se države koje spadaju u kategorije LICUS ili $L H D$, ili i jedno i drugo. Zemlje srednjeg društvenog razvoja (medium human development) označene su sa $M H D$, a zemlje visokog društvenog razvoja (high human development) označene su sa $H H D$.

Tabela 2 - Rizici i bezbednosni problemi u zemljama koje proizvode naftu i gas. Izvor: UNDP

\begin{tabular}{|c|c|c|}
\hline ZEMLjA & $\begin{array}{c}\text { NIVO } \\
\text { RAZVOJA }\end{array}$ & RIZIK I BEZBEDNOSNI PROBLEMI \\
\hline \multicolumn{3}{|l|}{ Afrika } \\
\hline Alžir* & $M H D$ & Terorizam, otmice, kriminal \\
\hline Angola* & Slaba država & Kriminal, nagazne mine, pobuna u provinciji Cabinda \\
\hline Cad & Slaba država & Pobune, političko nasilje, kriminal \\
\hline Kongo & Slaba država & Hapšenja, političko nasilje, kriminal \\
\hline Egipat & $M H D$ & $\begin{array}{c}\text { Terorizam, kriminal, otmice, fundamentalističke } \\
\text { grupe }\end{array}$ \\
\hline Ekvatorijalna Gvineja & $H H D$ & Diktatorski režim, političko nasilje, kriminal \\
\hline Gabon & $H H D$ & Blizu slabih država, diktatorski režim \\
\hline Libija* $^{*}$ & $H H D$ & Diktatorski režim, terorističko utočište \\
\hline Madagaskar & $M H D$ & Političko nasilje, pobune, kriminal \\
\hline Malavi & Slaba država & Političko nasilje, kriminal \\
\hline Nigerija* & Slaba država & Pobune, piratstvo, otmice, političko nasilje \\
\hline Zambija & Slaba država & Milicije iz DRK, kriminal, nagazne mine \\
\hline \multicolumn{3}{|l|}{ Azija / Bliski Istok } \\
\hline Azerbejdžan & MHD & Političko nasilje, civilne žrtve, kriminal \\
\hline Kambodža & Slaba država & Političko nasilje, civilne žrtve, nagazne mine \\
\hline Indonezija* & $M H D$ & Terorizam, kriminal, piratstvo \\
\hline $\operatorname{Iran}^{*}$ & MHD & Civilne žrtve, kriminal, sankcije SAD \\
\hline Kazahstan & $H H D$ & Civilne žrtve, ekstremizam u regionu \\
\hline & $H H D$ & Terorizam, otmice, piratstvo \\
\hline
\end{tabular}

${ }^{40}$ Ortiz, C.: Isto, str. 102. 
Bezbednost

\begin{tabular}{c|cc}
\hline ZEMLjA & NIVO & RIZIK I BEZBEDNOSNI PROBLEMI \\
\hline Pakistan & RHDOJA & Terorizam, talibani, nasilje, kriminal \\
Filipini & MHD & Terorizam, kriminal, otmice \\
Rusija & $H H D$ & Političko nasilje, kriminal, terorizam \\
Saudijska Arabija* & $H H D$ & Terorizam, civilne žrtve \\
Sirija & MHD & Terorističko utočište, sankcije SAD \\
Tajland & MHD & Političko nasilje, terorizam, separatizam \\
Latinska Amerika & MHD & Političko nasilje, kriminal \\
Bolivija & HHD & Kriminal, otmice, pobunjenici na granici sa Kolumbijom \\
Brazil & MHD & Terorizam, otmice, kriminal \\
Kolumbija & HHD & Civilne žrtve, kriminal, otmice \\
Venecuela* & (MHD)srednji društveni razvoj & (HHD) visok društveni razvoj \\
\hline * članice OPEC & \multicolumn{2}{c}{}
\end{tabular}

\section{Privatne vojne kompanije u sistemu unutrašnje bezbednosti države}

Termin „Bezbednost otadžbine“ ili „Unutrašnja bezbednost države“ („Homeland security") naglo je popularizovan nakon terorističkih napada na SAD 11. septembra 2001. godine. U suštini, unutrašnja bezbednost države oduvek je smatrana delom sistema nacionalne bezbednosti jedne zemlje. ${ }^{41} \mathrm{~S}$ druge strane, određenje pojma države treba tražiti u kombinaciji shvatanja države kao organizacije i nosioca društvenih funkcija. Neosporno je da je država izvesna organizacija vršenja vlasti, a njeni elementi ljudi i njihove delatnosti, kao i organizacija tih ljudi u vršenju delatnosti, tj. vlasti. ${ }^{42}$ Nacionalna bezbednost tradicionalno podrazumeva očuvanje državnog integriteta i stabilnosti, kao i borbu protiv unutrašnjih i spoljašnjih agresora. U SAD , pod unutrašnjim bezbednosnim pretnjama obično se smatraju razni oblici organizovanog kriminala, organizovane bande, agresivni oružani napadi i incidenti izazvani od strane poremećenih osoba ili grupa, kao i sporadične „domaće“ terorističke aktivnosti. Policijske službe i druge bezbednosne agencije uspešno rešavaju ove unutrašnje probleme, ali istorijski posmatrano pažnja SAD uglavnom je bila usmerena na borbu protiv spoljašnjih agresora (neprijatelja) i nacionalu odbranu. Za vreme hladnog rata, najveća opasnost za SAD pretila je od strane Sovjetskog Saveza, u vidu mogućeg nuklearnog napada koji bi došao iz te države. Ipak, celokupna slika se promenila nakon 11. septembra 2001. godine. Unutrašnja bezbednost države postala je u nekom smislu način razmišljanja o ozbiljnim pretnjama unutar državnih granica, sa akcentom na moguće nove i velike terorističke napade. ${ }^{43}$ Poseban značaj, kada je reč o SAD, dat je terminu „American Homeland“ (američka domovina) ili „Homeland“ (domovina) koji se prema zakonu o osnivanju Sekretarijata unutrašnje bezbednosti SAD iz 2002. godine, odnose na SAD u geografskom smislu. ${ }^{44}$

\footnotetext{
${ }^{41}$ Ortiz, C.: Isto, str. 104.

${ }^{42}$ Mijalković, S.: Nacionalna bezbednost. Beograd: Kriminalističko-policijska akademija, 2009.

${ }^{43}$ Ortiz, C.: Isto, str. 105.

${ }^{44}$ Bajagić, M.: Špijunaža u XXI veku: Savremeni obaveštajno-bezbednosni sistemi. Beograd: MARSO, 2010, str. 103.
} 
Na sličan način kao što se privatni vojni sektor, nakon Drugog svetskog rata, integrisao u sistem nacionalne odbrane SAD, i privatne vojne kompanije iz SAD su nakon 11. septembra 2001. godine postale jedan od glavnih elemenata sistema unutrašnje bezbednosti te države. Nakon 11. septembra 2001. godine i terorističkih napada na SAD, došlo je do brzog obnavljanja saradnje između država u cilju rešavanja problema izazvanih delovanjem međunarodnog terorizma. Kao jedan od elemenata ove saradnje, 28. septembra 2001. godine, Rezolucijom 1373 Saveta bezbednosti Ujedinjenih nacija (UN Security Council) formiran je Komitet Ujedinjenih nacija za borbu protiv terorizma (UN CounterTerrorism Committee). Ovaj komitet bavi se različitim zadacima i pitanjima, kao što su međunarodna saradnja u istrazi terorističkih aktivnosti, finansiranje terorističkih aktivnosti od strane međunarodnih kriminalnih grupa, kao i jačanje zakonske regulative u cilju krivičnog gonjenja počinilaca krivičnih dela terorizma. ${ }^{45}$ Kao rezultat svega ovog, došlo je do ažuriranja starih, ali i donošenja novih konvencija Ujedinjenih nacija o terorizmu Sve navedene aktivnosti predstavljaju neku vrstu institucionalnih mera i odgovora na problem međunarodnog terorizma. To uključuje i mnoštvo novih rezolucija, uredbi, zakona, propisa, ali i tehnologije koje države koriste u pokušaju da spreče terorističke napade. Važnu ulogu u svemu ovom imaju međunarodne institucije i organizacije koje nadgledaju primenu ovih mera. Napori koji se ulažu od strane međunarodne zajednice u cilju prevencije i suzbijanja terorističkih aktivnosti mogu se videti svuda, pa čak i na međunarodnim aerodromima, gde se, pored povećane bezbednosne provere lični i biometrijski podaci čuvaju u velikim bazama podataka, koje se stalno proveravaju u cilju otkrivanja osoba koje su povezane sa terorističkim aktivnostima. Slično tome, Međunarodni brodski i lučki bezbednosni (International Ship and Port Facility Security - ISPS) kod uveo je niz mera koje su namenjene povećanju bezbednosti brodova i lučkih objekata. ${ }^{46}$

Institucionalni odgovor međunarodne zajednice na pitanje terorizma $u$ isto vreme je označio i sistematski ulazak privatnih vojnih kompanija na tržište unutrašnje bezbednosti mnogih država . Naime, dok su međunarodna tela definisala aktivnosti i zadatke koje treba izvršiti, a vlade država preduzele korake neophodne kako bi se te aktivnosti međusobno uskladile, neke informaciono-tehnološke, vojno-industrijske, i bezbednosne korporacije bile su odgovorne u smislu tehničko-tehnološke realizacije ovih aktivnosti. Segmenti unutar tih korporacija (hibridne privatne vojne kompanije), na primer, pružaju obuku pilotima vojnih snaga SAD kako da koriste novu opremu i letelice. Takođe, nije redak slučaj da se privatne vojne kompanije (njihovi instruktori i osoblje), na osnovu ugovora koje imaju sa Ministarstvom odbrane SAD ili nekom drugom državnom službom ili agencijom, angažuju kako bi pružili pomoć i asistenciju prilikom rukovanja sličnom opremom. Privatna vojna kompanija Garda svet (Garda World) pruža upravo ovakvu vrstu usluga na međunarodnom aerodromu Pirson (Pearson) u Torontu, Kanada. ${ }^{47}$ Isto tako, nakon uvođenja ISPS koda, mnoge privatne vojne kompanije su razvile tehnologiju, obučile stručan kadar i nastavile da pružaju pomoć (usluge) lučkim vlastima širom sveta u cilju poboljšanja i unapređenja pomorske bezbednosti.

\footnotetext{
${ }^{45}$ Videti opširnije na: http://www.un.org/en/sc/ctc/. Pristupljeno 11 oktobra 2018. godine u 14 časova.

${ }^{46}$ Nordquist, M.; Moore, J.: Current maritime issues and the international maritime organization. Boston: Martinus Nijhoff Publishers, 2004, str. 158.

${ }^{47}$ Preuzeto 12. decembra 2011. godine sa http://www.garda-world.com/
} 
U SAD, tržište unutrašnje bezbednosti pošireno je 2001. godine donošenjem akta za Ujedinjenje i jačanje Amerike obezbeđivanjem odgovarajućih sredstava potrebnih za presretanje i opstruiranje terorizma (Uniting and Strengthening America by Providing Appropriate Tools Required to Intercept and Obstruct Terrorism - USA PATRIOT), kao i osnivanjem Sekretarijata unutrašnje bezbednosti (Department of Homeland Security $D H S) .{ }^{48}$ Ovaj sekretarijat je uspostavio saradnju i partnerski odnos, kada je reč o bezbednosnim aktivnosti i operacijama, sa velikim brojem korporacija (privatnih vojnih kompanija) uključenih u projektovanje i proizvodnju novih tehnologija koje se koriste u oblasti bezbednosnog nadzora i obaveštajnog rada. ${ }^{49} \mathrm{Na}$ primer, Teroristička identifikaciona baza podataka u okruženju (Terrorist Identities Datamart Environment - TIDE), je klasifikovana baza podataka koja u sebi sadrži imena oko 50.000 terorista, osumnjičenih i potencijalnih terorista. ${ }^{50}$ Hiljade terminala dnevno pristupaju ovoj ogromnoj informaciono-tehnološkoj bazi podataka, koja je napravljena od strane vojno-industrijske korporacije Lokid Martin (Lockheed Martin), a pod patronatom Rejlhed (Railhead) programa unapređena od strane Boinga (Boeing), SRI (SRI International), i desetine drugih subkontraktora. U Velikoj Britaniji, projekat Ovladati Internetom (Mastering the Internet - MTI) ima za cilj da prati dešavanja svih aktivnosti na Internetu, u cilju prevencije kriminalnih ili terorističkih aktivnosti. ${ }^{51}$ Korporacije kao što su Lokid Martin i Detika (Detica) stoje iza ovog projekta. Zanimljiv je i jedan podatak iz jula 2009. godine, kada su neki od korisnika mobilnih telefona marke Blekberi, u Ujedinjenim Arapskim Emiratima, otkrili da njihova vlada koristi aplikacije za prisluškivanje, razvijene od strane kalifornijske kompanije SS8 (SS8), kako bi pratila i prisluškivala njihovu komunikaciju (telefonske razgovore i SMS poruke).

Izvan vladinog sektora, multinacionalne korporacije i međunarodne organizacije koje sebe vide kao potencijalne mete terorističkih napada, poveravaju poslove koji se odnose na procenu rizika i bezbednosne usluge privatnim vojnim kompanijama. Privatna kompanija Istražna služba SAD (U.S. Investigations Services, Inc.), koja je do 1996. godine bila u sastavu vlade SAD, sprovodi obaveštajne istrage i bezbednosne provere zaposlenih u nekoliko vladinih agencija, a takođe ima ugovore sa nekoliko komercijalnih kompanija i klijenata. ${ }^{53}$ U Francuskoj je 2009. godine izbio veliki skandal kada je otkriveno da je energetska korporacija EDF (EDF) angažovala privatnu vojnu kompaniju Kargus konsultanti (Kargus Consultants), kako bi prisluškivala i pratila aktivnosti nevladine organizacije Grinpis (Greenpeace), u Evropi. Naime, EDF se bavi nuklearnom energijom, a Grinpis je antinuklearna nevladina organizacija. Godine 2009, londonska kompanija Međunarodna

\footnotetext{
${ }^{48}$ Videti opširnije na „The USA PATRIOT Act: Preserving Life and Liberty“, United States Department of Justice

${ }^{49}$ Shodno utvrđenoj viziji i misiji, strateški ciljevi Sekretarijata unutrašnje bezbednosti su direktno povezani sa tri strateška cilja Nacionalne strategije unutrašnje bezbednosti SAD, kao što su: angažovanje u cilju otkrivanja i sprečavanja pretnji koje prestavljaju opasnost po bezbednost američkog naroda, i zaštitu svih ljudi od pretnji i rizika; uvažavanje i poštovanje američkih veza sa partnerima i poslovnim ljudima, na temeljima očuvanja slobode i demokratije-koncepta na kojima počiva ugled SAD. Videti, Bajagić, M.: Isto, str. 109.

${ }^{50}$ Videti opširnije na: http://www.nctc.gov/docs/Tide_Fact_Sheet.pdf. Pristupljeno 8. oktobra 2018. godine.

${ }^{51}$ Burghart, T.: Spying on Individuals and Organisations: Anglo-American Defence Giants Entrusted with „Mastering the Internet", 2008. Deo teksta preuzet 12. decembra sa http://www.globalresearch.ca/index.php?context=va\&aid=13540

${ }^{52}$ Videti opširnije na: http://news.bbc.co.uk/2/hi/technology/8161190.stm. Pristupljeno 11. septembra 2018. godine.

${ }^{53}$ Videti opširnije na: http://www.sourcewatch.org/index.php?title=US_Investigations_Services. Pristupljeno 5. septembra 2018. godine.
} 
bezbednosna rešenja (International Security Solutions) učestvovala je u razotkrivanju afere o zloupotrebi troškova koje su počinili mnogi članovi britanskog parlamenta. Primera je mnogo, ali kada ovakvi i slični slučajevi izađu u javnost, postavlja se pitanje uticaja koji privatne vojne kompanije imaju na radno i poslovno okruženje.

\section{Uloga privatnih vojnih kompanija u borbi protiv organizovanog kriminala}

U Rezoluciji 1373 Saveta bezbednosti Ujedinjenih nacija, navodi se da postoji jaka veza između međunarodnog terorizma i transnacionalnog organizovanog kriminala. ${ }^{54} \mathrm{Te}-$ roristi mogu biti politički motivisani, ali motiv stvaranja nelegalnog profita, koji stoji iza organizovanog kriminala, može biti povezan sa terorističkim aktivnostima. Na primer, pranje novca, ilegalna trgovina oružjem, ilegalna trgovina i prenos nuklearnog, hemijskog, biološkog, i drugog potencijalno smrtonosnog materijala takođe se pominju u Rezoluciji 1373. Zbog toga se organizovani kriminal u isto vreme mora posmatrati i kao pomoćno sredstvo u cilju sprovođenja terorističkih aktivnosti. Takođe, on predstavlja i pretnju sam za sebe, imajući u vidu da u zoni sive ekonomije (u podzemlju) kriminalne organizacije mogu da nabave bilo šta a da njihove aktivnosti ostanu neprimećene. Dokle god negde postoje pobunjenici koji žele da nabave oružje, teroristi koji žele da dođu u posed nekog smrtonosnog materijala ili obični građani koji žele da kupe neku vrstu nelegalne tj. „zabranjene" robe, postojaće mafijaške grupe i kriminalne bande koje će biti u mogućnosti i spremne da im to obezbede. Ovde ne smemo zaboraviti ni sajber kriminal koji svakodnevno nanosi veliku štetu svetskoj ekonomiji. Prema nekim analitičarima, ova šteta se procenjuje na oko jedan trilion dolara godišnje.

Bez obzira na mnoga „lica“ organizovanog kriminala i pretnje koju on predstavlja za mir i stabilnost, trgovina narkoticima zaslužuje posebnu pažnju u ovoj analizi. Stotine milijardi dolara vredna nelegana trgovina narkoticima je transnacionalno preduzeće koje prkosi redu i zakonu na globalnom nivou. U vezi s tim, izveštaj Kancelarije Ujedinjenih nacija za drogu i kriminal (United Nations Office on Drugs and Crime), pod nazivom Svetski izveštaj o drogi 2009. (World Drug Report 2009), ustanovio je da Avganistan i dalje važi za vodećeg proizvođača opijuma (od kojeg se pravi heroin), a Kolumbija (81.000 hektara zasada), Peru (56.100 hektara) i Bolivija (30.500 hektara), ostaju vodeći proizvođači drveta koke (od kojeg se pravi kokain). ${ }^{55}$ Južna Afrika, Albanija, Jamajka i Paragvaj pominju se kao proizvođači oko $25 \%$ biljke kanabisa, a Maroko kao najveći snabdevač smole kanabisa (oko $21 \%$ tržišnog udela). U isto vreme, proizvodnja amfetamina (u koju se ubraja i ekstazi), koji se sintetizuje u tajnim laboratorijama širom sveta, beleži porast.

Ova bogata ponuda nalazi se nasuprot jednako velikoj potražnji, posebno na tržištima u Evropi i Severnoj Americi. Primeri koji su ovde dati mogu da približe i pojasne sliku gusto isprepletenih krijumčarskih mreža po celom svetu, kojima rukovode velike organizacije za trgovinu narkoticima, zajedno sa velikim brojem mafijaških grupa i kriminalnih bandi. Pobunjeničke grupe, kao što su Talibani u Avganistanu i Pakistanu, i terorističke organizacije po-

\footnotetext{
${ }^{54}$ United Nations, "Security Council Resolution S/RES/1373 (2001)". New York, September 28, 2001.

${ }^{55}$ United Nations Office on Drugs and Crime, World Drug Report 2009. New York: United Nations, 2009, str. 63.
} 
put, FARC u Kolumbiji, finansiraju svoje nasilne kampanje i akcije preko trgovine drogom i iz tog razloga su povezane sa organizovanim kriminalom. Narkoterorizam danas, bez sumnje, prestavlja najbolji primer simbioze organizovanog kriminala i terorizma. ${ }^{56}$

Kao i u slučaju borbe protiv terorizma, postoji i institucionalna dimenzija kada je reč o aktivnostima koje se preduzimaju od strane država i međunarodnih organizacija koje se bave problemom trgovine narkoticima. Tu su i bilateralni sporazumi između država koje zahtevaju stranu bezbednosnu asistenciju (pomoć) i onih država koje se suočavaju sa velikim brojem zavisnika i velikom potrošnjom na tržištu. Pomoć od strane SAD, kao podrška Planu Kolumbija (Plan Colombia), od 2000. godine, i Merida inicijativa (Merida Initiative) za Meksiko, Centralnu Ameriku, Dominikansku Republiku i Haiti, samo su primeri ovakvih sporazuma. Privatne vojne kompanije kao što su Međunarodni DinKorp i Vojni profesionalni resursi, imaju veliko iskustvo u pružanju usluga protivnarkotičke obuke u Latinskoj Americi, Africi, i na Bliskom Istoku. ${ }^{57}$ Usluge koje pružaju ove privatne vojne kompanije pokrivaju kako teorijsku, tako i praktičnu obuku, gde su česti slučajevi da instruktori privatnih vojnih kompanija prate bezbednosne (vojne i policijske) snage za vreme akcija na terenu. Učešće i uloga privatnih vojnih kompanija u borbi protiv trgovine narkoticima, nalazi se na meti raznih kritičara, imajući u vidu da dovodi do većeg stepena militarizacije čitavog problema. Međutim, treba imati u vidu da protivnarkotičke operacije i aktivnosti imaju za cilj da u celu priču ubace i vojnu komponentu, zbog toga što većina organizacija koje se bave trgovinom narkoticima imaju svoje paramilitarne grupe. Ove grupe ponekad čine i nekoliko stotina dobro obučenih i opremljenih ljudi, a postoji i stalna tendencija da se u njihovim redovima i za njihove poslove angažuju bivši pripadnici specijalnih jedinica, kao i razni plaćenici. Da bi se ove i ovakve strukture porazile, često je neophodno upotrebiti smrtonosnu silu. ${ }^{58}$

\section{Zaključak}

Nova bezbednosna „arhitektura“ privatnog vojnog tržišta obuhvata brojne zadatke u oblasti borbenih operacija, obuke, podrške, bezbednosti, obaveštajnog rada, kao i poslova obnove i rekonstrukcije infrastrukture i objekata u postkonfliktnim područjima i zonama visokog bezbednosnog rizika. Ovo su ujedno i glavne oblasti koje za sada pokrivaju privatne vojne kompanije. Naravno, ova lista poslova nije konačna i ima sve tendencije da se u budućnosti proširi. Mnoge privatne vojne kompanije su uglavnom male firme, specijalizovane za obavljanje određenih vrsta poslova. Ipak, postoje i velike vojno-industrijske multinacionalne korporacije koje se bave poslovima uglavnom izvan "klasičnog" privatnog vojnog sektora, a koje takođe nude i privatne vojne usluge.

Na primer, neka informaciono-tehnološka korporacija može biti uključena u razvoj i proizvodnju poverljivog obaveštajnog tehničkog sistema ili baze podataka za Ministarstvo odbrane (Department of Defense - DOD) SAD, iako se ona uglavnom bavi projektovanjem i proizvodnjom avionskih uređaja i elektronike. Slično ovome, neka druga korporacija koja se bavi poslovima projektovanja i izgradnje može ostvariti veliki profit gradeći voj-

\footnotetext{
${ }^{56}$ Mijalković, S.: Isto, str. 268.

${ }^{57}$ Thomas, J.; Kümmel, G.: Isto, str. 141.

${ }^{58}$ Ortiz, C.: Isto, str. 108.
} 
ne objekte (vojne baze i pomoćni objekti za pripadnike oružanih snaga). Na taj način, ona pruža pomoć i podršku $D O D$-u SAD prilikom raspoređivanja vojnih snaga u inostranstvu. Kako bi se analitički pristupilo ovom problemu, analiziranom u okviru ovog specijalističkog rada, ovakve vrste firmi klasifikovane su kao hibridne forme privatnih vojnih kompanija. Naime, one predstavljaju segmente ili samostalne celine u okviru velikih korporacija, koje, između ostalog, nude i privatne vojne usluge. Upravljanje monopolom sile (nasilja) kroz bezbednosna partnerstva između države i privatnih vojnih kompanija za sada pati od mnogih nedostataka, posebno kada je reč o odgovornosti i regulisanju odnosa na privatnom vojnom tržištu. Ipak, svedoci smo sve većeg broja tužbi i sudskih procesa koji se vode protiv privatnih vojnih kontraktora, što ukazuje na to da se ovaj problem shvata veoma ozbiljno (posebno u SAD).

Bezbednosna partnerstva između države i privatnih vojnih kompanija zasnivaju se na strategiji koja je zamišljena tako da se određeni poslovi (ugovori) realizuju u periodu od nekoliko godina do jedne ili dve decenije. Ovo je veoma važno, zbog toga što se neki dugoročni odbrambeni i bezbednosni zadaci, ali i ciljevi, jednostavno ne smeju prekidati, tj. mora postojati neka vrsta kontinuiteta, jer se samo na taj način garantuje uspeh. Intenzivna saradnja između vlada mnogih država i privatnih vojnih kompanija garantuje budućnost nekih novih ugovora (kao i poslova koji se vezuju za te ugovore) i vodi ka sve čvršćim i zrelijim vezama između javnog i privatnog sektora. Zbog toga postoje jaki razlozi za tvrdnju da će bezbednosna partnerstva i privatne vojne kompanije metastazirati u kamen temeljac državne odbrane i bezbednosti u 21. veku. Taj novi fenomen će dugo vremena biti neprevaziđen. Potraga za bezbednim izvorima energije može veoma lako da pretvori prirodna bogatstva u izvore novih konflikata i oružanih sukoba. Na primer, autonomna oblast na severu Iraka, koja je naseljena Kurdima, bogata je naftom. S druge strane „režim“ koji kontroliše ovu oblast je u nekoj vrsti konflikta sa vladom u Bagdadu, zbog podele prihoda od prodaje nafte. Na drugom kraju države, gde se nalaze iračka naftna izvozna postrojenja, postoje teritorijalni sporovi između Kuvajta, Iraka i Irana. Velika nalazišta nafte i gasa u oblasti Artika mogla bi u budućnosti da dovedu do političkih, ekonomskih pa čak i oružanih konflikata između Kanade, Danske, Norveške, Rusije i SAD, imajući u vidu da postoje preklapanja u zahtevima ovih država na pravo korišćenja ovih prirodnih resursa itd.

\section{Literatura}

[1] Adeniran, W.: Democracy and military dictatorship in Africa. Lagos: Shalom Goldlinks Concept, 2003, str. 58.

[2] BBC. "Profile: Idriss Deby." BBC News, February 2, 2008.

[3] Brooks, D.: "From Humble Beginnings in Freetown: The Origins of the IPOA Code of Conduct," Journal of International Peace Operations 3, no. 5, 2008, str. 9.

[4] Burghart, T.: Spying on Individuals and Organisations: Anglo-American Defence Giants Entrusted with „Mastering the Internet“, 2008. Deo teksta preuzet 12. decembra sa

[5] Department of Defense, Annual Report to the President and the Congress. Washington, DC: Department of Defense, 1995, "Part V: Defense Management," http://www.dod.mil/execsec/adr95/index.html.

[6] Department of the Army, Contractors on the Battlefield: Field Manual (FM 3-100.21). Washington, DC: Department of the Army, 2003, paras. 1-29. 
[7] Edwards, S.: Swarming On The Battlefield: Past, Present, And Future. San Diego: Rand Publishing, 2000, str. 25.

[8] Eeben Barlow.: Executive Outcomes: Against All Odds. Alberton, South Africa: Galago Books, 2007, str. 540.

[9] Energy Information Administration, "September 2009 International Petroleum Monthly" (Washington, DC, November 10, 2009), http://www.eia.doe.gov/ emeu/ipsr/t21.xls.

[10] Ghazvinian, J.: Untapped: The Scramble for Africa's Oil. New York: Harcourt, 2008, str. 257.

[11] Girassol: A Stepping Stone for the Industry (Courbevoie, France: TOTAL, September 19, 2008), str. 31-36; i "Angola's Deepwater Girassol Field Comes on Stream," Press Release (Courbevoie, France, December 4, 2001).

[12] International Institute for Strategic Studies, The Military Balance1998-1999. Oxford: Oxford University Press, 1998, str. 270.

[13] Kwame Boafro, A.: Ghana: one decade of the liberal state. London: Zed Books, 2007, str. 120.

[14] National Archives and Records Administration, United States. President (1993-2001 : Clinton), Bill Clinton, United States. Office of the Federal Register.: Public Papers of the Presidents of the United States, William J. Clinton, 1996, Book 2, July 1 to December 31. Washington: Government Printing Office, 2000, str. 1088.

[15] Nordquist, M.; Moore, J.: Current maritime issues and the international maritime organization. Boston: Martinus Nijhoff Publishers, 2004, str. 158.

[16] Ortiz, C.: "The New Public Management of Security. The Contracting and Managerial State and the Private Military Industry." Public Money and Management 30, br. 1 (2010): str. 35-41;

[17] Ortiz, C.: "The Private Military Company: An Entity at the Centre of Overlapping Spheres of Commercial Activity and Responsibility," in Private Military and Security Companies: Chances, Problems, Pitfalls and Prospects (ed. Thomas Jäger and Gerhard Kümmel). Wiesbaden, Germany: VS Verlag, 2007, str. 55-68.

[18] Ortiz,C.: "The Private Military Company: An Entity at the Centre of Overlapping Spheres of Commercial Activity and Responsibility," in Private Military and Security Companies: Chances, Problems, Pitfalls and Prospects (ed. Thomas Jäger and Gerhard Kümmel). Wiesbaden, Germany: VS Verlag, 2007, str. 55-68.

[19] Ramirez, F.: The profits of extermination: how U.S. corporate power is destroying Colombia. Monroe, Common Courage Press, 2005, str. 39.

[20] Reno, W.: "African Weak States and Commercial Alliances," 96, no. 383 African Affairs, 1997, str. 167.

[21] Rubin, E.: "An Army of One's Own: In Africa, Nations Hire a Corporation to Wage War," Harper's Magazine (February 1997): str. 45.

[22] Singer, P.W.: Corporate Warriors: The Rise of the Privatized Military Industry. New York: Cornell University Press, 2003, str. 119-125.

[23] Stockholm Peace Research Institute, SIPRI Yearbook 1998: Armaments, Disarmament and International Security. Oxford: Oxford University Press, 1998, str. 20.

[24] The USA PATRIOT Act: Preserving Life and Liberty“, United States Department of Justice

[25] Thomas, J.; Kümmel, G.: Private military and security companies: chances, problems, pitfalls and prospects. Wiesbaden: VS Verlag, 2007, str. 66.

[26] United Nations Office on Drugs and Crime, World Drug Report 2009. New York: United Nations, 2009, str. 63.

[27] United Nations, "50 Years of United Nations Peacekeeping Operations, 1948-1998". New York: October 1998, http://www.un.org/en/peacekeeping/sites/50years/2.htm. 
[28] United Nations, "Security Council Resolution S/RES/1373 (2001)". New York, September 28, 2001.

[29] United Nations, "United Nations Peacekeeping: Questions and Answers". New York, September 1998, http:// www.un.org/Depts/dpko/dpko/question/faq.htm.

[30] Van Metre L.; Akan, B.: Special Repot: Dayton Implementation: The Train and Equip Program. United States Institute of Peace, 1997, str. 2.

[31] World Bank Independent Evaluation Group, Engaging with Fragile States: An IEG Review of World Bank Support to Low-Income Countries under Stress 2006. Washington, DC: World Bank, 2006, str. 3.

[32] Bajagić, M.: Špijunaža u XXI veku: Savremeni obaveštajno-bezbednosni sistemi. Beograd: MARSO, 2010, str.103

[33] Veb sajt Sekretarijata mirovnih operacija Ujedinjenih Nacija: http:// www.un.org/en/peacekeeping/.

[34] Videti na: http://www.sourcewatch.org/index.php?title=US_Investigations_Services

[35] Videti opširnije na: http://www.un.org/Depts/DPKO/Missions/unmibh_p.htm. Pristupljeno 15.09.2018. godine.

[36] Mijalković, S.: Nacionalna bezbednost. Beograd: Kriminalističko-policijska akademija, 2009.

[37] Milašinović, R; Milašinović, S.: Uvod u teorije konflikata. Beograd: Fakultet civilne odbrane Univerziteta u Beogradu, 2004.

[38] Stajić, Lj.; Gilanović, Č.: Osnovi bezbednosti. Beograd: Policijska akademija u Beogradu, 1994. 